\title{
Bioinspired bioartifical polymer hybrid composites for propolis vaginal delivery I: formulation development and optimization of gelling temperature using experimental design
}

\author{
Maja Simonoska-Crcarevska*, Ana Zafirovska-Gapkovska, Kristina Mladenovska, \\ Renata Slavevska Raicki, Nikola Geskovski, Simona Dimcevska, Marija Glavas-Dodov \\ Institute of pharmaceutical technology, Faculty of pharmacy, "Ss. Cyril \& Methodius" University, Majka Teresa 47, \\ Skopje, R. Macedonia \\ Center of pharmaceutical nanotechnology, Faculty of pharmacy, "Ss. Cyril \& Methodius" University, Majka Teresa 47, \\ Skopje, R. Macedonia
}

Received: April 2013; Accepted: June 2013

\begin{abstract}
Polymer hybrid composites for propolis vaginal delivery were developed and optimized in term of gelling temperature (Tg) using experimental design studies. Formulation of intelligent delivery system, with in situ gelling and controlled release properties, was carried out by bioartificial blending of chitosan and poloxamers, Lutrol ${ }^{\circledR} \mathrm{F} 127$ and Lutrol ${ }^{\circledR} \mathrm{F} 68$.

Response-surface, Box-Behnken, experimental design was applied for determination of key factors influencing $T g$. Influence of Lutrol ${ }^{\circledR}$ F127 concentration, Lutrol ${ }^{\circledR}$ F68/Lutrol ${ }^{\circledR}$ F127 mass ratio and volume of simulated vaginal fluid was evaluated. Derived correlations enabled formulation optimization in term of $\operatorname{Tg}\left(32^{\circ} \mathrm{C}\right)$. The model was cross-validated. Confirmation report and relative error percent of predicted and experimental values were obtained.
\end{abstract}

Key words: bioinspired polymer hybrid composites, propolis, vaginal delivery, experimental design

\section{Introduction}

Bacterial vaginosis and vulvovaginal candidiasis are the most common causes of vaginal infections and they are often referred as symptomatic vaginitis. Conventional approach encompasses use of antibiotics and antimycotics delivered in form of solutions, foams, tablets and pessasries as well as rings, creams and gels (Morlion, 2009). The choice of the most appropriate delivery system will depend on different considerations: required effect (local or systemic), drug release (immediate or controlled) and patient acceptability (Woolfson et al., 2007).

\footnotetext{
* e-mail: msimonoska@ff.ukim.edu.mk tel.: +38923126032 ; fax: +38923123054
}

Conventional vaginal drug delivery systems are associated with multiple days of dosing, dripping, leakage and messiness, causing discomfort to users and expulsion due to the self-cleansing action of the vaginal tract (Yenkar et al., 2013), hence leading to poor patient compliance and unfulfilled desired therapeutic efficacy. Having in mind previous, bioinspired vaginal delivery system should be developed thus offering the advantages of easy administration and spreading in the vagina, slow clearance from local sites allowing prolonged drug release at the desired site of action and hence resulting with better therapeutic efficacy. The rational approach would comprise bioartifical blending of natural and synthetic polymers conferring to unique structural and mechanical properties of the de- 
signed delivery system. By bioartificial blending the concept of biomimicry of several materials can be developed leading to new generation of intelligent vaginal delivery systems (Sionkowska, 2011). Efficient bioresponsive system for vaginal delivery could be formulated using thermo sensitive, $\mathrm{pH}$ responsive and/or ion activated polymer along with mucoadhesive polymers in order to accomplish the desired physico-chemical and biopharmaceutical properties required for efficacious and safe therapy.

One of the most commonly used thermosensitive materials are poloxamers i.e. polyethylene oxide - propylene oxide - polyethylene oxide block copolymers (PEO-PPOPEO) recognized under the proprietary name of Lutrol ${ }^{\circledR}$, especially Lutrol ${ }^{\circledR}$ F127 and Lutrol ${ }^{\circledR}$ F68 characterized by biocompatibility and good compatibility with various drugs and pharmaceutical excipients. The additional advantages are easy availability and simple method for gel preparation and drug loading (Koffi et al., 2006). Addition of bio/mucoadhesive macromolecules to the PEO-PPOPEO based delivery system would result with prolonged residence time along with sustained drug release at the site of action. Blending of PEO-PPO-PEO based polymer systems with other bio/mucoadhesive polymers would result in substantially improved bio/mucoadhesive properties and at the same time surmounting possible rapid gel erosion due to weak mechanical strength (Varshosaz et al., 2008; Yuan et al., 2012). Therefore chitosan is a promising adjuvant, especially due to its additional antimicrobial and antifungal activity (Peña et al., 2013; Tikhonov et al., 2006).

Having in mind that propolis biological and pharmacological properties as antimicrobial and antifungal agent are well known and documented (Sforcin and Bankova, 2011), propolis thermosensitive gel with bio/mucoadhesive properties was developed with rationale of efficacious treatment of vaginal infections. Experimental design studies were used for development and optimization of propolis vaginal delivery system with in situ gelling properties. Lutrol ${ }^{\circledR}$ F127, Lutrol ${ }^{\circledR}$ F68 and chitosan (low viscous, $95 \%$ deacetilation) were used for polymer hybrid composites with desired, thermoresponsive, bio/mucoadesive and prolonged local drug release features. Having in mind that in vivo, designed formulations will be subjected to the dilution with vaginal fluids, the volume of vaginal fluid (usually $\sim$ up to $0.75 \mathrm{ml}$ ) (Owen and Katz, 1999) was also considered as one of the parameters affecting their properties.

\section{Material and methods}

\section{Materials}

Chitosan (low viscous, 95\% deacetilation) (CTS) was obtained from Sigma-Aldrich, USA. Lutrol® ${ }^{\circledR} 127$ and Lutrol ${ }^{\circledR}$ F68 were purchased from BASF (Ludwigshaften, Germany). 20\% propylene-glycolic extract of propolis was kindly donated by Galafarm, Macedonia. All other chemicals were with analytical grade and used as received.

\section{Preparation of thermosensitive gels}

Cold method (Schmolka, 1972) with minor modification was used for preparation of in situ gels. Briefly, 1.5\% CTS solution was prepared by dissolving CTS powder in $1 \%$ lactic acid under gentle stirring (300 rpm). Afterwards, propylene-glycolic extract of propolis as active agent and hence, potassium sorbate as preservative were added. Various amounts of Lutrol ${ }^{\circledR}$ F127 and Lutrol ${ }^{\circledR}$ F 68 were added gradually under continuous agitation $(200 \mathrm{rpm})$ until total dissolution. Obtained viscous solutions were kept for $24 \mathrm{~h}$ at $4{ }^{\circ} \mathrm{C}$ to eliminate foam and air bubbles. The final concentration of propolis in prepared formulations was $3 \%(\mathrm{w} / \mathrm{w})$.

\section{Experimental design}

Response surface method (RSM) is empirical statistical technique that uses quantitative data derived from designed experiments in order to determine the regression pattern and working conditions (Alam et al., 2007; Garg et al., 2008; Ricou-Hoeffer et al., 2001; Tan et al., 2008). Graphical display of their dependence is called response surface and applying this approach, description of the individual and cumulative effects of the studied variables and their impact on appropriate responses could be done. The main objective of RSM is determining the optimal values of variables in order to obtain the desired values of responses (Myers and Montgomery, 1971). Application of statistical experimental design during the development of the formulation may reduce the variability of the procedure, the time of performing the experiments and the total cost, thus resulting with better overall results (Annadurai, 2000).

Response-surface, Box-Behnken design is an independent quadratic design where designed combinations are at the midpoints of edges of the deigned space and at the center. This design is rotatable and requires 3 levels of each factor. Compared to response surface, central composite design it requires fewer designed combinations in cases involving same number of factors. Its "missing corners" may be useful when the experimenter should avoid combined factor extremes thus preventing a potential loss of data in those cases (Chopra et al., 2007a). The quadratic-model could be described by the Eq. 1:

$$
\begin{aligned}
& Y=b_{\mathrm{o}}+b_{1} X_{1}+b_{2} X_{2}+b_{3} X_{3}+b_{12} X_{1} X_{2}+b_{13} X_{1} X_{3}+ \\
& b_{23} X_{2} X_{3}+b_{11} X_{1}^{2}+b_{22} X_{2}^{2}+b_{33} X_{3}^{2}
\end{aligned}
$$

where $\mathrm{Y}$ is the measured response associated with each factor level combination; $b_{0}$ is an intercept; $b_{1}$ to $b_{33}$ are regression coefficients computed from the observed experimental values of $Y$; and $X_{1}, X_{2}$ and $X_{3}$ are the coded levels of independent variables. The terms $\mathrm{X}_{1} \mathrm{X}_{2}$ and $\mathrm{X}^{2} \mathrm{i}(\mathrm{i}=1,2$ or 3 ) represent the interaction and quadratic terms, respectively (Box and Behnken, 1960; Chopra et al., 2007a; Chopra et al., 2007b).

Having in mind the previous, response-surface, BoxBehnken experimental design (Design Expert ${ }^{\circledR}$ V8; Stat- 
Design-Expert@ Software

Factor Coding: Actual

Geling Temperature

- Design points above predicted value

$\circ$ Design points below predicted value

$\square_{16}^{49}$

$\mathrm{X} 1=\mathrm{A}: \mathrm{F} 127$

$\mathrm{X} 2=\mathrm{B}: \mathrm{F} 68 / \mathrm{F} 127$

Actual Factor

C: Vaginal fluid $=0.38$

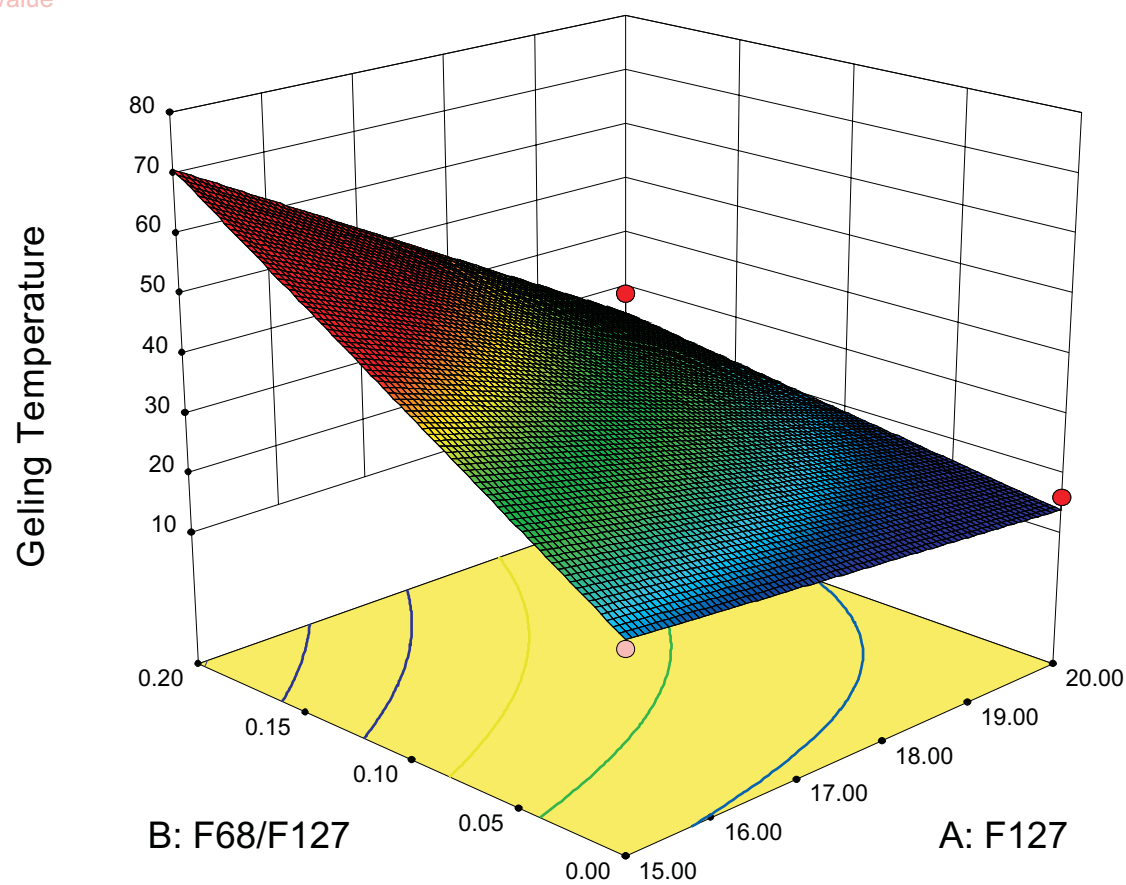

Fig.1. Estimated surface plots ilustrating the dependence of the response from selected model terms.

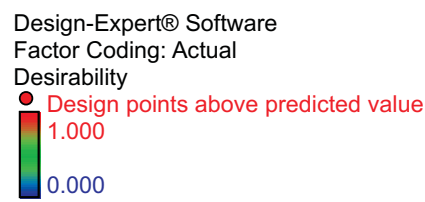

$\mathrm{X} 1=\mathrm{A}: \mathrm{F} 127$

$\mathrm{X} 2=\mathrm{B}: \mathrm{F} 68 / \mathrm{F} 127$

Actual Factor

C: Vaginal fluid $=0.75$

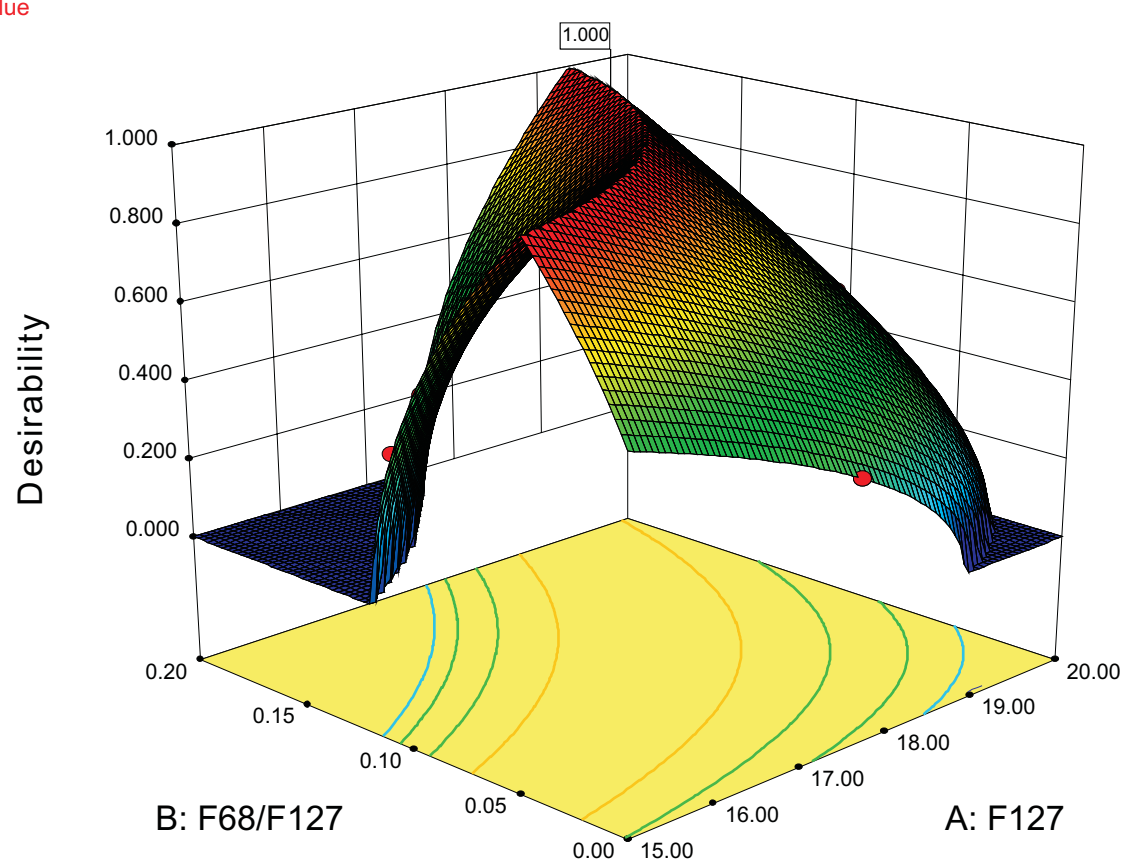

Fig. 2. Desirability graph for $T g$ response.

Макед. фарм. билт., 59 (1, 2) 33 - 40 (2013) 
Ease Inc., Minneapolis, MN) was applied for determination of the influence of concentration of Lutrol ${ }^{\circledR}$ F127 (factor A), Lutrol ${ }^{\circledR}$ F68/ Lutrol ${ }^{\circledR}$ F127 mass ratio (factor $\mathrm{B}$ ) and volume of simulated vaginal fluid (SVF) (factor C) upon the gelation temperature $(\mathrm{Tg})$ of the designed system with in situ gelling properties. The design matrix was constructed in one block where all factors were varied at $3 \mathrm{lev}-$ els, with 5 central points and the total of 17 experiments were carried out.

Low and high level values, coded and actual, of varied variables are presented in Table 1, while designed experiments are presented in Table 2. Experiments were carried out at random.

\section{Determination of gelation temperature (Tg)}

Gelation temperature $(\mathrm{Tg})$ of the designed formulations was determined using "Visual Tube Inversion Method" (Ur-Rehman et al., 2010) with minor modifications. Briefly, $2 \mathrm{ml}$ of prepared samples were placed in glass tubes, designated amount of SVF was added and tubes were put in a horizontal shaker water bath (50 strokes/ $\mathrm{min})$. The temperature of the water bath was gradually increased $\left(1{ }^{\circ} \mathrm{C} / \mathrm{min}\right)$ and the temperature at which the solution in the sample containing tube stopped flowing upon inverting the tube was recorded. Similarly, the temperature was decreased and the temperature, at which the gel started flowing, was recorded. The average of both temperatures was calculated as the critical $T g$.

\section{Results and discussion}

\section{Experimental design}

In the formulation development stage, response-surface, Box-Behnken, experimental design (Design Expert ${ }^{\circledR}$ V8; Stat-Ease Inc., Minneapolis, MN) was applied for determination of key factors affecting the $T g$ (Table 2) of the in situ mucoadhesive vaginal hydrogels. The concentration of Lutrol ${ }^{\circledR}$ F127 (15-20\%), Lutrol ${ }^{\circledR}$ F68/ Lutrol ${ }^{\circledR}$ F127 mass ratio (0-0.2) and the volume of SVF $(0-0.75 \mathrm{ml})$ were investigated as study variables and all factors were varied at 3 levels. 2FI model was suggested for describing the influence of variables upon the $T g$. ANOVA for response surface 2 FI model indicated that concentration of Lutrol ${ }^{\circledR}$ F127, Lutrol ${ }^{\circledR}$ F68/ Lutrol ${ }^{\circledR}$ F127 mass ratio and their interaction are significant model terms that goverend $T g$.

Estimated surface plots ilustrating the dependance of the $\mathrm{Tg}$ response from selected model terms is presneted on Fig.1

Final equation (Eq. 2) for $T g$ in terms of coded factors is:

$$
\begin{gathered}
\text { Geling Temperature }=+32.82-13.11 \cdot A+15.36 \cdot B \\
+0.25 \cdot C-9.6 \cdot A \cdot B-0.12 \cdot A \cdot C-0.12 \cdot B \cdot C(\text { Eq. } 2)
\end{gathered}
$$

Negative value of A indicated its inverse correlation influence on the followed response i.e. its increament would result with lower $T g$ while positive value of B suggested that by increasing the amount of Lutrol ${ }^{\circledR}$ F68 in the Lutrol ${ }^{\circledR}$ F68/ Lutrol ${ }^{\circledR}$ F127 ratio, the $T g$ would be higher. The positive correlation influence was determined for SVF influence. Interaction terms $(\mathrm{AB}, \mathrm{AC}$ and $\mathrm{BC})$ were found to have negative influence upon $T g$, where only $\mathrm{AB}$ interaction therm has significant $T g$ influence.

Albiet, $T g$ of specific polymer system depends on the molecules behaviour in the solution. Temperature-reversible polymer hybrid composites are consisted of molecule agregates physically juncted at specific polymer concetration and enviroment temperature, preceded by coiling of biopolymer chains and forming of double helices (Guenet, 1992). As, Lutrol ${ }^{\circledR} 668$ and Lutrol ${ }^{\circledR} F 127$ are three block copolymers consisted of hydrophilic PEO and hydrophobic PPO blocks at given concentration and temperature, molecules self association occurs and most likely driving force for gel formation is creation of micelles ordering into lattices. Presumably, PPO blocks are forming hydrophobic central core while PEO blocks are part of hydrophilic outer shell, thus interacting very strongly with itself and forming temporary crosslinks trough hydrophobic interaction, van-der Waals and hydrogen bonding (Bromberg and Ron, 1998; Escobar-Chávez et al., 2006). The observation for inverse relation of $T g$ with concentration of Lutrol ${ }^{\circledR}$ F127 are in accordance with literature data about stability regions of ordered micelle strucutres of Lutrol $\mathbb{R}$ and especially cubic three-dimensional lattices (gels) that moves towered lower temperatures at higher concentration (Bromberg and Ron, 1998) i.e. higher concentration would result with micelles packaging at lower temperatures.

Obtained results for $T g$ (Table 2) were in favor of the rationale behind Lutrol ${ }^{\circledR}$ F127 and Lutrol ${ }^{\circledR}$ F68 blending that resulted in $T g$ modulation. The findings about influence of Lutrol ${ }^{\circledR}$ F68 amount in the Lutrol ${ }^{\circledR}$ F68/ Lutrol ${ }^{\circledR}$ F127 ratio upon $T g$ (higher amount of Lutrol ${ }^{\circledR}$ F68 resulted with increased $T g$ ), are correlated with the work of others (Ibrahim et al., 2012; Jeong et al., 2012; Radivojša et al., 2013). It is generally accepted that the PPO, which is hydrophobic, has lowered $T g$ and the PEO, which is hydrophilic, has increased Tg. According to findings of Ibrahim et al. (Ibrahim et al., 2012) addition of Lutrol ${ }^{\circledR}$ F68 to Lutrol ${ }^{\circledR}$ F127 leads to increased $T g$ most likely due to changes of PEO/PPO ratio. Namely, the ratio of PEO/PPO in Lutrol ${ }^{\circledR} F 127$ is $7: 3$, while in Lutrol ${ }^{\circledR} F 68$ it is 8:2 thus when a certain amount of Lutrol ${ }^{\circledR}$ F68 is added to Lutrol ${ }^{\circledR}$ F127 the proportion of PEO increases leading to an increase in $T g$. Similar were the findings of Radivojša and co. and Jeong and co. (Jeong et al., 2012; Radivojša et al., 2013). As they suggest, this observation could be explained by the dehydration of PPO. Having in mind that proportion of PPO in Lutrol ${ }^{\circledR}$ F68 is lower than in Lutrol ${ }^{\circledR}$ F127, gelation would occur at higher concentration and/ or higher 
Table 1. Coded and actual values of independent experimental variables

\begin{tabular}{lccccc}
\hline \multicolumn{1}{c}{ Factor } & \multicolumn{2}{c}{ Low } & \multicolumn{2}{c}{ High } \\
& Coded & $\begin{array}{l}\text { Actual } \\
\text { values }\end{array}$ & $\begin{array}{l}\text { Coded } \\
\text { values }\end{array}$ & $\begin{array}{l}\text { Actual } \\
\text { values }\end{array}$ \\
& -1 & 15 & +1 & 20 \\
\hline A: concentration of Lutrol@ F127(\%) & -1 & 0 & +1 & 0.2 \\
B: Lutrol@ F68/ Lutrol ${ }^{\circledR}$ F127(w/w) & -1 & 0 & +1 & 0.75 \\
C: volume of simulated vaginal fluid (ml) & & & & & \\
\hline
\end{tabular}

Table 2. Experimental design points for studied independent experimental variables in coded values and obtained response for designed formulations, ANOVA output statistics for measured response and optimized batches with predicted $\mathrm{Tg}$ and cross validation of the model

\begin{tabular}{|c|c|c|c|c|c|c|c|c|}
\hline Std & Run & Block & $\begin{array}{c}\text { Factor } 1 \\
\text { A: } \\
\text { F127* }\end{array}$ & $\begin{array}{c}\text { Factor } 2 \\
\text { B: } \\
\text { F68 / F127* }\end{array}$ & $\begin{array}{c}\text { Factor } 3 \\
\text { C: } \\
\text { SVF }\end{array}$ & $\begin{array}{c}\text { Response } \\
\operatorname{Tg}\left({ }^{\circ} \mathrm{C}\right)\end{array}$ & \multicolumn{2}{|c|}{ ANOVA output statistics } \\
\hline 15 & 1 & $\{1\}$ & 0 & 0 & 0 & 32.5 & Suggested model & $2 \mathrm{FI}$ \\
\hline 6 & 2 & $\{1\}$ & 1 & 0 & -1 & 19 & & \\
\hline 17 & 3 & $\{1\}$ & 0 & 0 & 0 & 32.5 & Sum of Square & 2091.91 \\
\hline 16 & 4 & $\{1\}$ & 0 & 0 & 0 & 32,5 & & \\
\hline 1 & 5 & $\{1\}$ & -1 & -1 & 0 & 19.5 & Degrees of freedom & 6 \\
\hline 14 & 6 & $\{1\}$ & 0 & 0 & 0 & 32.5 & & \\
\hline 8 & 7 & $\{1\}$ & 1 & 0 & 1 & 19 & Mean square & 348.65 \\
\hline 4 & 8 & $\{1\}$ & 1 & 1 & 0 & 29 & F-value & 62.72 \\
\hline 9 & 9 & $\{1\}$ & 0 & -1 & -1 & 16 & Prob $>F$ & $<0.0001$ \\
\hline 2 & 10 & $\{1\}$ & 1 & -1 & 0 & 16 & SD & 2.36 \\
\hline 11 & 11 & $\{1\}$ & 0 & -1 & 1 & 17 & Mean & 30.44 \\
\hline 7 & 12 & $\{1\}$ & -1 & 0 & 1 & 49 & $\mathrm{CV} \%$ & 7.75 \\
\hline 3 & 13 & $\{1\}$ & -1 & 1 & 0 & / & PRESS & 361.53 \\
\hline 12 & 14 & $\{1\}$ & 0 & 1 & 1 & 46 & $\mathrm{R}^{2}$ & 0.9766 \\
\hline 10 & 15 & $\{1\}$ & 0 & 1 & -1 & 45.5 & Adj- $R^{2}$ & 0.9611 \\
\hline 13 & 16 & $\{1\}$ & 0 & 0 & 0 & 32.5 & Pred- $\mathrm{R}^{2}$ & 0.8312 \\
\hline 5 & 17 & $\{1\}$ & -1 & 0 & -1 & 48.5 & Adequate precision & 22.034 \\
\hline
\end{tabular}

Optimized batches with predicted $T g$ and cross validation of the model

Factors

$\begin{array}{ccc}\text { Run } & \mathrm{F} 127^{*}(\%) & \begin{array}{c}\mathrm{F} 68 / \mathrm{F} 127^{*} \\ (\mathrm{w} / \mathrm{w})\end{array} \\ 1 & 16.39 & 0.06 \\ 2 & 17.36 & 0.09 \\ 3 & 18.24 & 0.12\end{array}$

Response

$\begin{array}{cc}\text { SVF } & \text { Pred. } \\ (\mathrm{ml}) & \operatorname{Tg}\left({ }^{\circ} \mathrm{C}\right)\end{array}$

0.75

0.75

32

32

0.75

Experimental
$\operatorname{Tg}\left({ }^{\circ} \mathrm{C}\right)$

31

31.8

31.9
1- Bias

$(\%)$

3.125

0.625

0.313

* F68 - Lutrol@ F68; F127 - Lutrol@ F127 


\section{temperatures.}

Having in mind that the main objective of the this work was to develop bioresponsive system for vaginal delivery $T g$ of polymer hybrid composites was investigated in the presence of different amounts of SVF thus biomimicring in vivo conditions. Although SVF influence upon $\mathrm{Tg}$ was not considered statistically significant, a positive influence was noticed. SVF dilution of formulations resulted with slight increase in $\mathrm{Tg}$. This could be attributed not only to the decrease in polymers concentration but also to the possible modification of physicochemical properties of the polymer hybrid composites (Aka-Any-Grah et al., 2010). Presumably, the $T g$ increase is related to the increase of the critical micelle concentration or a increase of the critical micelle temperature, or both.

ANOVA statistics for the fitted model for the followed response is presented in Table 2. The predicted $\mathrm{R}^{2}$ (Pred$\mathrm{R}^{2}$ ) and the adjusted $\mathrm{R}^{2}\left(\mathrm{Adj}-\mathrm{R}^{2}\right)$ should be within 0.20 of each other. Otherwise there may be a problem with either the data or the model. Adj-R $\mathrm{R}^{2}$ and Pred- $\mathrm{R}^{2}$ values were in a reasonable agreement, signifying excellent model fit. $\mathrm{R}$ squeared values are higher than 0.95 and adequat precison values are greater than 4 indicating that all suggested models can be used to navigate the design space (Makraduli et al., 2013).

The derived correlations enabled further formulation optimization in term of required temperature for in situ gelling $\left(32^{\circ} \mathrm{C}\right)$. Optimized batches with predicted $\mathrm{Tg}$ of 32 ${ }^{\circ} \mathrm{C}$ were identified (Table 2).

Desirability value is dependent on how the lower and upper limits are set relative to the actual optimum. The goal of optimization is to find a good set of conditions that will meet all the goals, not to get to a desirability value of 1.0. Desirability is simply a mathematical method to find the optimum. The numerical optimization finds a point that maximizes the desirability function. The characteristics of a goal may be altered by adjusting the weight or importance. For several responses and factors, all goals get combined into one desirability function. Desirability graph for $\mathrm{Tg}$ responses is presented on Fig. 2.

Cross-validation of the model was carried out. Confirmation report and the per-cent of relative error of the predicted and experimental values were obtained (Table 2).

\section{Conclusion}

In this study, a novel approach based on thermosensitive bio/mucoadhesive hydrogel system for prolonged release of propolis was developed. Based on the results obtained it can be concluded that chitosan-Lutrol ${ }^{\circledR}$ based systems seem as an attractive candidates for local vaginal delivery of propolis. This attractive approach will be evaluated in further in vitro and in vivo studies carried out on the optimized batches.

\section{References}

Aka-Any-Grah, A., Bouchemal, K., Koffi, A., Agnely, F., Zhang, M., Djabourov, M., Ponchel, G., 2010. Formulation of mucoadhesive vaginal hydrogels insensitive to dilution with vaginal fluids. Eur. J. Pharm. Bipharm. 76(2), 296-303.

Alam, Z., Muyibi, S. A., Toramae, J., 2007. Statistical optimization of adsorption processes for removal of 2,4-dichlorophenol by activated carbon derived from oil palm empty fruit bunches. J. Environ. Sci. 19(6), 674-677.

Annadurai, G., 2000. Design of optimum response surface experiments for adsorption of direct dye on chitosan. Bioprocess Eng. 23(5), 451-455.

Box, G. E. P., Behnken, D. W., 1960. Some new three level designs for the study of quantitative variables. Technometrics 2(4), 455-475.

Bromberg, L. E., Ron, E. S., 1998. Temperature-responsive gels and thermogelling polymer matrices for protein and peptide delivery. Adv. Drug Deliv. Rev. 31(3), 197-221.

Chopra, S., Motwani, S. K., Iqbal, Z., Talegaonkar, S., Ahmad, F. J., Khar, R. K., 2007a. Optimisation of polyherbal gels for vaginal drug delivery by box-behnken statistical design. Eur. J. Pharm. Bipharm. 67(1), 120-131.

Chopra, S., Patil, G. V., Motwani, S. K., 2007b. Release modulating hydrophilic matrix systems of losartan potassium: Optimization of formulation using statistical experimental design. Eur. J. Pharm. Bipharm. 66(1), 73-82.

Escobar-Chávez, J., López-Cervantes, M., Naik, A., Kalia, Y., Quintanar-Guerrero, D., Ganem-Quintanar, A., 2006. Applications of thermo-reversible pluronic f-127 gels in pharmaceutical formulations. J. Pharm. Pharmaceut. Sci. 9(3), 339-358.

Garg, U. K., Kaur, M., Garg, V., Sud, D., 2008. Removal of nickel (ii) from aqueous solution by adsorption on agricultural waste biomass using a response surface methodological approach. Bioresource Technol. 99(5), 1325-1331.

Guenet, J. M., 1992. Thermoreversible gelation of polymers and biopolymers, ed. Academic Press, London.

Ibrahim, E.-S., Ismail, S., Fetih, G., Shaaban, O., Hassanein, K., Abdellah, N., 2012. Development and characterization of thermosensitive pluronic-based metronidazole in situ gelling formulations for vaginal application. Acta Pharm. 62(1), 5970.

Jeong, B., Kim, S. W., Bae, Y. H., 2012. Thermosensitive sol-gel reversible hydrogels. Adv. Drug Deliv. Rev.

Koffi, A. A., Agnely, F., Ponchel, G., Grossiord, J. L., 2006. Modulation of the rheological and mucoadhesive properties of thermosensitive poloxamer-based hydrogels intended for the rectal administration of quinine. Eur. J. Pharm. Sci. 27(4), 328-335.

Makraduli, L., Crcarevska, M. S., Geskovski, N., Dodov, M. G., Goracinova, K., 2013. Factorial design analysis and optimisation of alginate-ca-chitosan microspheres. J. Microencapsul. 30(1), 81-92.

Morlion, E. 2009. Development of a thermosensitive and mucoadhesive vehicle, based on poloxamer and chitosan, for vaginal administration of drugs, Ghent University.

Myers, R., Montgomery, D. C., 1971. Allyn-Bacon, Boston, Massachusetts.

Owen, D. H., Katz, D. F., 1999. A vaginal fluid simulant. Contraception 59(2), 91-95.

Peña, A., Sánchez, N. S., Calahorra, M., 2013. Effects of chitosan 
on candida albicans: Conditions for its antifungal activity. BioMed Res. Int. 2013.

Radivojša, M., Grabnar, I., Grabnar, P. A., 2013. Thermoreversible in situ gelling poloxamer-based systems with chitosan nanocomplexes for prolonged subcutaneous delivery of heparin: Design and $<\mathrm{i}>$ in vitro $</ \mathrm{i}>$ evaluation. Eur. J. Pharm. Sci.

Ricou-Hoeffer, P., Lecuyer, I., Le Cloirec, P., 2001. Experimental design methodology applied to adsorption of metallic ions onto fly ash. Water Res. 35(4), 965-976.

Schmolka, I. R., 1972. Artificial skin i. Preparation and properties of pluronic f - 127 gels for treatment of burns. J. Biomed. Mater. Res. 6(6), 571-582.

Sforcin, J. M., Bankova, V., 2011. Propolis: Is there a potential for the development of new drugs? J. Ethnopharmacol. 133(2), 253-260.

Sionkowska, A., 2011. Current research on the blends of natural and synthetic polymers as new biomaterials: Review. Prog. Polym. Sci. 36(9), 1254-1276.

Tan, I., Ahmad, A., Hameed, B., 2008. Optimization of preparation conditions for activated carbons from coconut husk using response surface methodology. Chem. Eng. J. 137(3), 462-470.

Tikhonov, V. E., Stepnova, E. A., Babak, V. G., Yamskov, I. A., Palma-Guerrero, J., Jansson, H.-B., Lopez-Llorca, L.
V., Salinas, J., Gerasimenko, D. V., Avdienko, I. D., 2006. Bactericidal and antifungal activities of a low molecular weight chitosan and its $n$-/2 (3)-(dodec-2-enyl) succinoyl/derivatives. Carbohyd. Polym. 64(1), 66-72.

Ur-Rehman, T., Tavelin, S., Gröbner, G., 2010. Effect of dmso on micellization, gelation and drug release profile of poloxamer 407. Int. J. Pharm. 394(1), 92-98.

Varshosaz, J., Tabbakhian, M., Salmani, Z., 2008. Designing of a thermosensitive chitosan/poloxamer in situ gel for ocular delivery of ciprofloxacin. Open Drug. Deliv. J. 2, 61-70.

Woolfson, A. D., McCullagh, S. D., Morrow, R. J., Malcolm, R. K., 2007. Vagina and uterus as drug absorbing organs, in: Touitou, E.,Barry, B. W. (Eds), Enhancement in drug delivery. CRC Press, pp.

Yenkar, P., Mayee, R., Nawale, R., Chavan, R., Salunke, T., Bhoyar, V., 2013. Bio responsive in situ gel of clindamycin for vaginal application. RRJPPS 2(2), 26-32.

Yuan, Y., Cui, Y., Zhang, L., Zhu, H.-p., Guo, Y.-S., Zhong, B., Hu, X., Zhang, L., Wang, X.-h., Chen, L., 2012. Thermosensitive and mucoadhesive in situ gel based on poloxamer as new carrier for rectal administration of nimesulide. Int. J. Pharm. 430(1-2), 114-119.

\title{
Биоинспирирани биовештачки полимерни хибридни композити со контролирано ослободување на прополис во вагина I: развој на формулација и оптимизација на температурата на гелирање со примена на експериментален дизајн
}

\author{
Маја Симоноска-Црцаревска, Ана Зафировска-Гапковска, Кристина Младеновска, \\ Рената Славеска Раички, Никола Гешковски, Симона Димчевска, \\ Марија Главаш-Додов
}

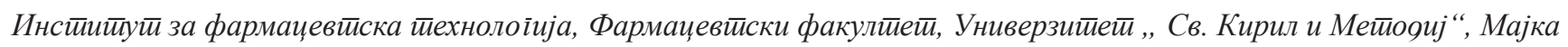
Тереза 47, Скойје, Р. Макеоонија

Клучни зборови: биоинспирирани полимерни хибридни композити, прополис, контролирано ослободување, вагинално локално делување, експериментален дизајн

Целта на овој труд беше формулација и оптимизација на полимерни хибридни композити со прополис со потенцијал за контролирано ослободување, локално во вагината. За формулацијата на интелегентен вагинален систем со особини за in situ гелирање и локално, контролирано ослободување на активната супстанција, беше применет концептот на биовештачко блендирање на цитозан (низок вискозитет, 95\% деацетилација), Lutrol® F127 и Lutrol® F68. 
Определувањето на факторите што влијаат на температурата на гелирање на дизајнираниот систем и оптимизацијата на формулацијата беше направено со примена на методите засновани на моделирање на површината на одговорот, Box-Behnken експерименталниот дизајн. При тоа беше евалуирано влијанието на концентрацијата на Lutrol@ F127, масениот однос на Lutrol® F68 / Lutrol® F127 и волуменот на симулирана вагинална течност врз температурата на гелирање. Сите фактори беа варирани на 3 нивоа и беа направени вкупно 17 формулации што беа карактеризирани од аспект на температурата на гелирање. Влијанието на испитуваните варијабли најдобро може да се опише со помош на 2FI моделот. Еднонасочната ANOVA за овој модел укажа дека статистички значајно влијание имаат концентрацијата на Lutrol® F127, масениот однос на Lutrol® F68 / Lutrol® F127 и нивната интеракција. Добиените резултати укажаа на негативна корелација меѓу температурата на гелирање и концентрацијата на Lutrol® F127, позитивна корелација со масениот однос на Lutrol® F68 / Lutrol® F127 и негативна корелација со нивното взаемно влијание. Утврдените зависности овозможија оптмизиација на формулацијата од аспект на потребната температура за in situ гелирање $\left(32^{\circ} \mathrm{C}\right)$. Моделот беше потврден со вкрстена валидација и беше определен процентот на релативна грешка на предвидените и експериментално добиените вредности. 